\title{
Leadership Self-Efficacy, Change Oriented Behavior and Organizational Citizenship Behavior: The Moderating Effect of Experience
}

\author{
Adebayo Saheed Adewale ${ }^{1}$, Hazri Jamil ${ }^{1} \&$ Adebayo-Shittabey Khadijah $^{2}$ \\ ${ }^{1}$ National Higher Education Research Institute, Universiti Sains Malaysia, Malaysia \\ 2 Al-Madinah International University, Malaysia \\ Correspondence: Adebayo Saheed Adewale, National Higher Education Research Institute, Universiti Sains Malaysia, \\ Malaysia. E-mail: sadebayo@usm.my
}

Received: June 2, 2019

doi:10.5430/ijhe.v8n4p36
Accepted: June 27, 2019

Online Published: July 2, 2019

URL: https://doi.org/10.5430/ijhe.v8n4p36

\begin{abstract}
Knowledge is an essential factor in human existence. Education has been found responsible for social, economic, cultural and technological development of human society. Higher education institutions are responsible for producing required skilled human capital needed to enhance sustainable development. For these institutions to meet up with numerous demand of the society and function effectively leadership is an essential factor to be considered. This study examined the effect of leadership self-efficacy, change oriented behavior on staff organizational citizenship behavior in higher education institutions focusing on the moderating effect of experience. A total of 420 staff from 10 different higher education institutions in Lagos State, Nigeria were sampled. Structural Equation Modeling was used to access the moderating effect of experience on these variables. It was found that experience moderates the relationship between leadership self-efficacy, change oriented behavior, change policy and organizational citizenship behavior. Therefore, experience must be considered as a vital factor in higher education management and development.
\end{abstract}

Keywords: leadership self-efficacy, change oriented behavior, organizational citizenship behavior, moderating effect, experience.

\section{Introduction}

Education has been found responsible for social, economic, cultural and technological development of human society (Zolfashari, 2015). Higher education institutions are responsible for expanding research infrastructure; served as a forum for generating, discussing and disseminating new ideas; training of skilled manpower needed for holistic development (Bolu \& Egbo, 2014). In order to meet up with the demand of the changing global community, effective leadership is considered an essential ingredient for effective higher education performance (Chuang, 2013; Haris, 2008; Bush \& Middlewood, 2005; Leaming 1999). The roles of leadership in higher institutions of learning go further to cover promotion of viable environment that will enhance academic development, promotion of learning and scholarship, ensuring collaboration with external and corporate bodies in the area of cutting edge research, re-branding the image of higher learning in meeting up with contemporary needs of the learners, society and global community, handling organizational conflict, and a host of others (Ijaz et al., 2012; Braun et al., 2009; Bryman \& Lilley, 2009; Spendlove, 2007; Kouzes \& Posner, 2003; Ramsden, 1998).

Corruption and ability to implement effective organizational change are part of fundamental factors affecting poor performance of higher education institutions especially in developing countries. Ejimabo (2013) highlights the poor situation of Nigerian university education, blaming government and academia for the poor performance of these institutions. Also, Nakpodia (2012) found that some of the people saddled with responsibility of leadership are not performing up to expectation due to corruption and bad leadership. The effect of poor leadership manifests in some events and drama happening in higher education institutions in the country (Aina et al., 2017; Ogunruku, 2012). In addition, implementation of change was found to be another obstacle facing higher education in Nigeria. Ineffective implementation of change has led to distortion in higher education programs in Nigeria (Okoroma, 2006). These hinder development of higher education greatly.

Previous study has investigated the interrelation among leadership self-efficacy, change oriented behavior and staff organizational citizenship behavior in higher education institutions and found that there is a statistically significant relationship between these variables (Adebayo et.al, 2018; Adebayo \& Ghavifekr, 2019). Therefore, this study aims at 
examining the moderating effect of experience on the interaction among leadership self-efficacy, change oriented behavior, change policy and staff organizational citizenship behavior in Nigerian higher education institutions.

\subsection{Theoretical and Conceptual Framework}

The first theory that guided this study is the Bandura theory of self-efficacy. It views people as self-reflecting, self-regulating, self-organizing, proactive and are driven by inner impulses. Bandura (1997) further stress that human functioning is the product of a dynamic interplay of behavioral, personal and environmental influences which he describes as reciprocal determinism. Bandura suggests that individuals will tend to select tasks and activities in which they feel confident and competent, and will avoid those in which they do not. Unless people believe that their actions will have the desired consequences, they have little incentive to engage in those actions (Bandura 2004; Bandura, 1997). The stronger the perceived self-efficacy, the more active the coping efforts (Van- der- Bijil \& Shortridge-Baggett, 2002). Therefore, Bandura (1997) categorized people into two groups in relation to their self-efficacy. These are high and low self-efficacy respectively. People with high self-efficacy set challenging goals, stay committed to the attainment of their set goals, show high dedication to work, display positive attitude, never give up even when task is difficult and put in high aspiration in accomplishing their set goals (Bandura,2007). In the contrast, people with low self-efficacy shy away from difficult tasks; show low aspirations to attainment of goals, give up easily when confronted with small or little work challenges, become anxious with tasks, complain a lot about given task and exhibit weak commitment to work (Bandura \& Locke,2003).

The second theory examined here is the Kouzes and Posner transformational leadership theory. It borrows much from Weber's idea about charisma. Kouzer and Posner (2007) developed their transformational leadership theory based on their research study and came up with five practices of a transformational leader including: (a) model the way (b) inspire shared vision (c) challenge the process (d) enable others to act, and (e) encourage the heart. To model the way, leaders must take time for consideration, reflect on the lessons from admired leaders, create alignment around key values of the organization, and speak about shared values of the organization with confidence and enthusiasm (Kouzer \& Posner, 2007). Also, inspiring shared vision implies that leaders must give their subordinates a vision of something to aim for, a purpose and establish a connection between themselves and their followers (Barbara \& Swailes, 2010; Kouzer \& Posner, 2007). It also connotes ability of leaders to bring his/her subordinates together towards a shared vision (Abu Tineh et.al, 2009). Challenging the process entails creating new ideas, recognizing and supporting new ideas, showing willingness to challenge the system in order to turn ideas into action and improve on the quality of service delivery, product and process (Yukl, 2010; Kouzer \&Posner, 2007; 2002). To enable others to act, leaders need to promote collaboration with others and encourage their subordinate to act at different capacity towards achieving goals of the organization (Kouzer \&Posner, 2007). Finally, encouraging the heart entails ability of leaders to motivate their followers towards accomplishing organizational goals and completing given tasks as at when due. When leaders adopt the transformational leadership style effectively, it will increase performance of staff and enhance productivity (Abu Nasri \& Helibrunn, 2015; Yukl, 2011; Owen \& Valesky, 2011; Brown \&Booking, 2005).

Theory of organizational citizenship behavior is the last theory in this study. This theory was propounded by Dennis Organ in 1988. Organ (1997) identified five common behaviors which he used to describe the organizational citizenship behavior theory. These include: altruism, sportsmanship, courtesy, civic virtue and consciousness. He argued that when these common behaviors are displayed in a group setting, it will result into more productivity and more effective work. Altruism is the desire to help another individual without expecting any form of reward or compensation for the assistance rendered (Organ, 1997). Also, he conceives sportsmanship as the act of not expressing wrong or negative feelings when things do not go as planned or expected. Courtesy is the act of being considerate and polite towards others. It involves caring for co-workers and showing concern for their welfare; sharing their joy, happiness and sorrow; showing concern for their work progress and family (Farh et.al, 2004; Organ, 1997). Furthermore, Organ (1997) describes civic virtue as behavior that shows how well an employee represents his or her organization or how well he or she associates and supports the organization while consciousness refers to behavior that suggests a reasonable level of self-control and discipline, which extends beyond the minimum requirement expected in a given situation. If all these behaviors are applied in the workplace, there will be mutual love, understanding, increase in production and healthy interaction among workers (Ehtiyar et.al.,2010; Organ et.al., 2006).Although modern psychologists have proposed numerous common positive organizational citizenship behavior, the Organ's five dimensions are still considered as the most significant (Farooqii, 2012; Ehtiyar et.al., 2010; Bukhari, 2008). Therefore, we proposed the conceptual framework below to guide this study. 


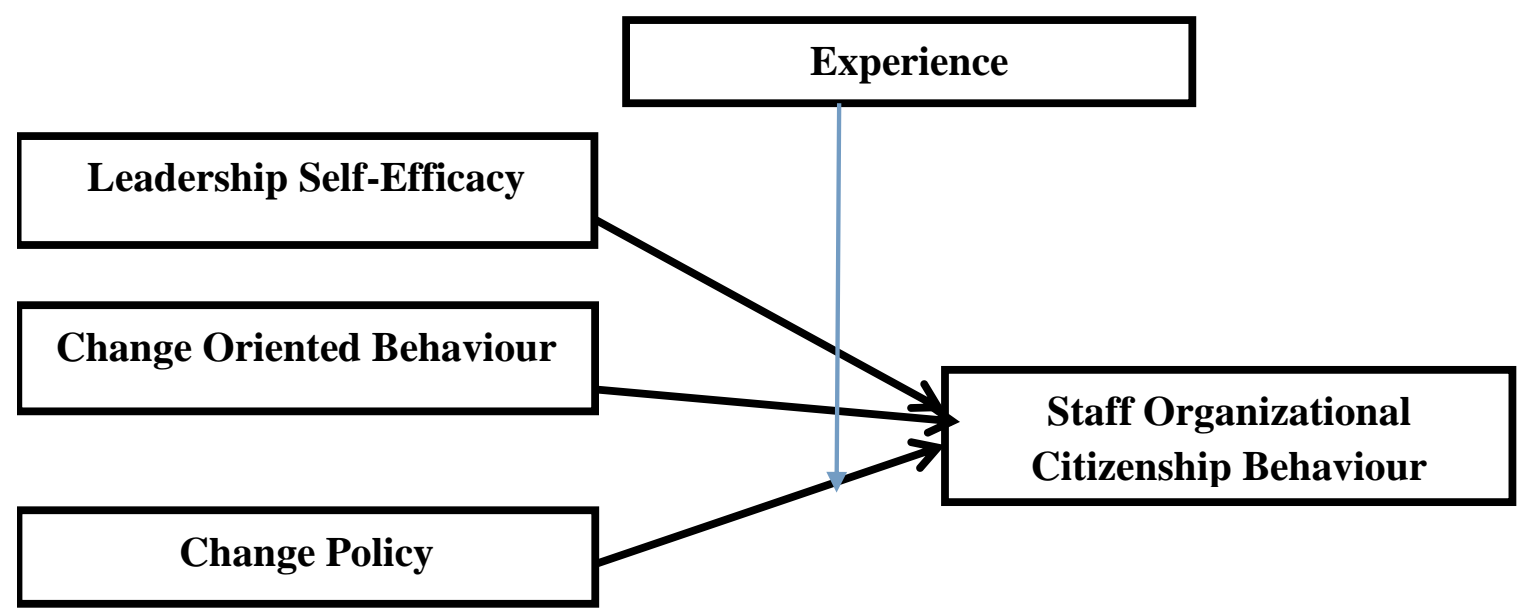

Figure 1: Conceptual Framework

The conceptual framework shows that leadership self-efficacy, change oriented behavior and change policy have relationship with staff's organizational citizenship behavior. It further reveals that experience can moderate the relationship among leadership self-efficacy, change oriented behavior and staff organizational citizenship behavior. This corresponds with findings of Adebayo et.al (2018) who found that leadership self-efficacy, change oriented behavior and change policy have significant relationship with staff's organizational citizenship behavior in Nigerian higher education institutions. It further shows that this relationship can be moderated by experience as experience stands in the model. Based on this model, we formulated and tested this research hypothesis:

Ho: Experience does not moderate the interaction between leadership self-efficacy, change-oriented behavior, change policy and staff's organizational citizenship behavior.

$\mathrm{H}_{1}$ : Experience moderates the interaction between leadership self-efficacy, change-oriented behavior, change policy and staff's organizational citizenship behavior.

\section{Literature Review}

\subsection{Leadership Self-Efficacy, Change Oriented Behavior, Change Policy and Organizational Citizenship Behavior}

Leaders play vital role in the development of higher education institutions. They often contribute towards success and failure of higher education institutions (Bush \& Middlewood, 2005; Moore \& Diamond, 2001). According to Lunenburg (2011), the term self-efficacy refers to task-specific version of self-esteem which influences people's ability to learn, motivation and performance. Bandura (1997) divided people into two broad categories in relation to their self-efficacy. These are people with high and low self-efficacy. He further argued that those with high self-efficacy are always willing and ready to take up new challenges, remain committed to their goals and avoid complaint on any given task. In the contrast, those with low self-efficacy avoid taking rigorous task and are always complaining when confronted with new challenges. Furthermore, Bandura (2004) argued that those who persist in subjectively threatening activities will eventually eliminate their inhibitions through corrective experience, whereas those who avoid what they fear, or who cease their coping efforts prematurely, will retain their self-debilitating expectations and defensive behavior. The self-efficacy of leaders is crucial in influencing effective leadership in an organization (Anderson et.al. 2008; Paglis \& Green, 2002). Leadership self-efficacy can be described as the belief hold by leaders about their ability to attain various task ahead of them (Paglis, 2010; Barclay et.al. 2007). This has a great effect on organizational performance (Luneburg, 2011; Chemers et.al., 2000; Bandura, 1997). In the study of Adebayo and Ghavifekr (2019) it was found that high leadership self-efficacy has a positive relationship with staff's organizational citizenship behavior. Past studies also affirm that there is a relationship between leaders' attitude, behavior, style and the performance of followers (Lunenburg, 2011; Avolio et.al. 2004; Bandura, 2004). Irrespective of the type of the organization involved, the leaders' behavior usually determines the success or failure of the organization (Sahin et al., 2014; Owens \& Valesky, 2011; Bass, 2010; Yukl, 2010; Fernandez, 2008; Somech, 2006).

According to Dawson and Andriopoulos (2014), the term change was conceived as something which comes with a new thing that replaces and refines what has gone before or previous practices. It also implies a shift in the process 
and manner of doing things which has effect on staff, clients and the organization (Glaser, 2006). On the other hand, organizational change refers to strategically planned alterations of various aspects of organization which aim at developing the efficiency and effectiveness of the organization (Cawsey et.al. 2012). For every change activities, plan and process to be effective, there is need for effective leadership (Yukl, 2010). Therefore, leadership is crucial to organizational change because it helps in achieving organizational goals by influencing and encouraging the task force within the organization (Collins, 2014; George \& Jones, 2012; Bush, 2008; Patridge, 2007).When leaders lead the path of change diligently, sincerely and effectively, followers' commitment to the organization will increase (Adebayo et.al., 2018; Kouzes \& Posner, 2013; Owen \&Valesky, 2012; Yukl, 2010).

Furthermore, previous studies have given different descriptions of the term organizational citizenship behavior (Foote \& Tang, 2008; Bukhari, 2008; Organ et al., 2006; Organ, 1997; Podsakoff et.al., 2000). Therefore, Organ (1997) provides an expanded review of the term where he defines it as an individual behavior that is discretionary, not directly recognized by the formal reward system and that, which in the aggregate promotes the effective functioning of the organization. According to him, discretionary, refers to the behavior which are not enforceable by the job description. This behavior is rather a matter of personal choice, such that its omission is not generally understood as punishable but its adoption will enhance performance of the organization (Farh et.al., 2004; Podsakoff et.al., 2009; Organ, 1997). Also, this behavior relates to ethical behavior which improves the performance of employees in an organization (Agarwal, 2016; Farooqui, 2012). Organizational citizenship behavior helps in enhancing effectiveness of an organization (Organ et al., 2006)

\subsection{Effect of Experience on Leadership Self-Efficacy, Change Oriented Behavior and Organizational Citizenship Behavior}

Experience is a moving force in learning. It is also described as the best teacher. The experience gained by leaders from their previous work, interaction with people and their society will be transferred to their current work place. Experience is essential ingredient in organization leadership. It shapes the thought, interaction and success of good leaders (Hallenbeck, 2017). This affects how they manage their subordinates in achieving organizational goals. Adebayo (2018) found that experience plays a great role in influencing organizational citizenship behavior of people in the workplace. Similarly, Bettin and Kennedy Jr. (1990) also found in that experience enhances performance of US Army captains. This corresponds with findings of Chan (2010) who found that leaders with experience tend to achieve positive organizational outcome. The experience of leaders and subordinates will manifest in their manner of interaction and dealing with their organization, attaining goals and overall performance (Airola et al., 2014). In addition, the study of $\mathrm{Ng}$ and Feldman (2013) affirms that longer job tenure (experience) has significant effect of citizen behavior of workers. Also, Bandura (1997) acknowledged the importance of experience when he identified it as a vital factor in self-efficacy. Kotur and Anbazhagan (2014) found that experience influences workers leadership style. Similarly, experience was also identified as essential factor in leading and managing organizational change. Nilakant and Ramnarayan (2006) maintain that experience will determine how far a leader can go, lead a successful team and how subordinate will perform in the workplace. Not only for leaders, has it also assisted subordinates. This view corroborates with the findings of Avolio et. al. (1990) when they found that experience is a good determinant of employee performance in the workplace.

\section{Methodology}

Research Design: Creswell (2012) stressed that research design focuses on minimizing the possibility of arriving at an incorrect causal inference from a given data. In this study, the researchers used inferential research design. Mayer (2013) argued that the inferential research design assists researchers in making perfect prediction from data.

Population and Sample: Fraenkel et.al (2015) conceived population as a complete set from which researchers draw their sample. In this study, the population comprises of members of staff from 10 public higher education institutions in Lagos State, Nigeria. The method of sample selection adopted in this study is random sampling technique. With this, every member of the population has equal chance and probability of been selected (Mayer, 2013). Therefore, a total of 420 staff were sampled in this study. This number corresponds with suggestion of sample selection suggested by Krejcie and Morgan (1970) sample table.

Instrumentation: The instrument used in this study is a survey questionnaire. The questionnaire comprises of 39 items which was used to extract information from members of staff from 10 different higher education institutions. In addition, the survey questionnaire was adapted from the study of Bandura (1997) on self-efficacy; Osipova and Ayupora (2013) on change management; Jutila (2007) on organizational change; Adebayo et.al (2018), Tang et al. (2011) on organizational policies, and Bukhari (2008) on organizational citizenship behavior. 
Reliability and Validation of the Instrument: The term reliability refers to the degree to which a measuring instrument is consistent over time on measures for similar population (Kraska-Miller, 2014). It is the consistency and dependability of an instrument (Neuman, 2014). For this research, we used Cronbach's Alpha to determine reliability of items in the instrument as presented in the Table below:

Table 1. Reliability Statistics for Variables

\begin{tabular}{lll}
\hline Variable (s) & N & Cronbach's Alpha \\
\hline Leadership Self-Efficacy & 10 & .891 \\
Change Policy & 9 & .899 \\
Change Oriented Behavior & 9 & .893 \\
Organizational Citizenship Behavior & 11 & .895
\end{tabular}

Table 1 above shows the result of reliability statistics for the four variables under review. It reveals that leadership self-efficacy has 10 items with a Cronbach's Alpha of .891. Also, change policy has 9 items with a Cronbach's Alpha of .899. In addition, change oriented behavior has 9 items with Cronbach's Alpha of .893 while organizational citizenship behavior has 11 items with a Cronbach's Alpha of 895 .

Validity on the other hand explains the degree and level of what we claim we are measuring (Mayers, 2013). Validity of an instrument implies that such instrument is meaningful and gives researcher confidence to draw conclusions from the sample of the population of the study (Rubin \& Rabbie, 2014; Creswell, 2012). Therefore, in this study, we used factor analysis to determine the validity of the research instrument. Below is the result obtained from the factor analysis:

The 39 items in the leadership self-efficacy, change policy, change- oriented behavior and organizational citizenship behavior were exposed to factor analysis by means of Statistical Package for Social Sciences (SPSS) version 21. Prior to this, the suitability of data for factor analysis was assessed. A careful examination of the correlation matrix shows the presence of many coefficients of .3 and above. In addition, the Kaiser-Mayer-Olkin value was .976 . This exceeds .6 as recommended by Kaiser (1970). The Bartlett's Test of Sphericity is statistically significant with $p$ $=.000$. These support the factorability of the correlation matrix. The principal component analysis shows the presence of four components with eigenvalue greater than 1, explaining $51.6 \%, 6.5 \%, 5.3 \%$ and $2.9 \%$, of the variance respectively. A cross examination of the scree plot graph reveals a break after the fourth component. Going by the Catell's (1966) scree test, it was decided to retain four components for further investigation. These four components solution explained a total of $66.3 \%$ of the variance with component 1 contributing $51.6 \%$, component 2 contributed $6.5 \%$, component 3 explained $5.3 \%$ and component 4 contributed $2.9 \%$ respectively.

Administration of the Instrument: This instrument was administered personally to the respondents in their respective higher education institutions. It took the researchers a period of 6 months to administer the survey questionnaire. Effort was made to make clarification where necessary. In all, a total of 530 questionnaires were distributed. Out of which only 420 were correctly filled and returned. Since, this number meets the required number suggested by Krejcie and Morgan, the researchers decided to proceed with the analysis.

Method of Data Analysis: Structural Equation Modeling (SEM) was used to analyze the data gathered in this study. Bryne (2010) conceived structural equation modeling as a form of statistical method which makes use of confirmatory approach in analyzing a structural theory in accordance with some phenomenon. Awang (2014) postulates that researchers make use of structural equation modeling in testing the already existing theory in order to come up with a substantial and concrete result on the proposed study. Structural equation modeling shows relationship between hidden structure which are not directly measured and was found useful in analyzing complex multiple variable models (Civelek, 2018; Tabachnick \& Fidell, 2013). There are various programs used in structural equation modeling, of all these programs, Analysis of Moment Structure (AMOS) is the easiest (Civelek, 2018). Therefore, Analysis of Moment Structure (AMOS) was used in analyzing structural equation modeling in this study. Detailed report is presented in the findings section.

\section{Findings}

Here, we present results which emanate from this research study as shown below: 
Table 2. Demographic Information of Respondents

\begin{tabular}{llll}
\hline Items & & N & Percentage (\%) \\
\hline Gender: & Male & 288 & 68.6 \\
Staff Category: & Female & 132 & 31.4 \\
& Academic & 303 & 72.1 \\
Institution: & Non-Academic & 117 & 27.8 \\
& University & 150 & 35.7 \\
Highest Academic Qualification: & College of Education & 137 & 32.6 \\
& Polytechnics & 133 & 31.7 \\
& PhD & 118 & 28.1 \\
Year of Work Experience: & Master Degree & 224 & 53.3 \\
& Bachelor Degree & 78 & 18.6 \\
& Less than 10 years & 301 & 71.7 \\
& More than 10 years & 119 & 28.3
\end{tabular}

As presented in Table 2 above, we found that $288(68.6 \%)$ of the respondents are male while $132(31.4 \%)$ are female. It was also found that $303(72.1 \%)$ of the respondents are academic staff while $117(27.8 \%)$ are non-academic staff in different higher education institution. On institution of respondents, it was found that $150(35.7 \%)$ of the respondents are staff in universities, $137(32.6 \%)$ are staff in teacher training institutions (Colleges of Education) while $133(31.7 \%)$ are staff in technical institutions (Polytechnics) in Lagos State, Nigeria. Furthermore, it was found that 78(18.6\%) of the respondents had Bachelor's degree; 224 (53.3\%) had Master's degree while 118 (28.1\%) had Doctor of Philosophy degree as their highest educational qualification. The result on academic qualification reveals that more respondents had Master degree than $\mathrm{PhD}$. This occurs as a result of the academic staff entry requirement for both Teacher Training Colleges (Colleges of Education) and Technical Colleges (Polytechnics) in the country. You do not need to have PhD before you are employed into Teacher Training Colleges and Technical Colleges in Nigeria. Finally, 301(71.7\%) of the respondents had worked for less than 10 years while 119 (28.3\%) had worked for over 10 years in their respective higher education institutions.

\subsection{Evaluating the Fitness of the Model Fit}

Here, we started by measuring the fitness of the model. This was done by using the confirmatory factor analysis. The result is presented in Figure 2 below.

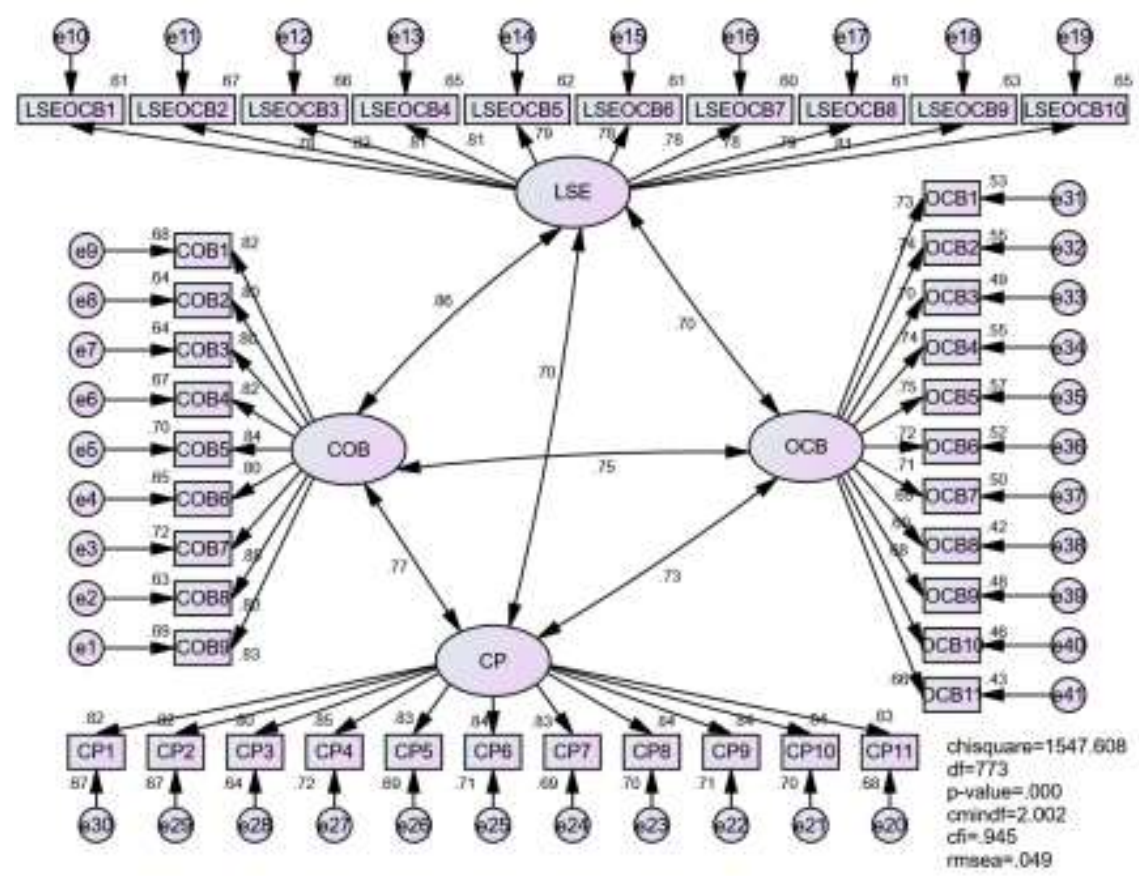

Figure 2. Model Fit Estimation 
The diagram in Figure 2 above shows the result of the confirmatory factor analysis of the 39 items. The loadings of the items in each of the constructs of leadership self-efficacy (LSE), change oriented behavior (COB), change policy (CP), and organizational citizenship behavior (OCB) are all above 0.6. Hair et al. (2017) suggested that a satisfactory loading should be between 0.7 and 0.9. Wong (2013) stated that loadings of 0.4 and above is accepted provided that other loadings in a construct are higher in order to compensate for average variance explained and composite reliability. Given this submission, the items of all the constructs in the model well satisfied the loadings criterion. The composite reliability of LSE, COB, CP and OCB have values of 0.7 and above. This satisfies the minimum criterion value of 0.7 are stated by Hair et al. (2017). It implies that the model satisfies the internal consistency reliability.

Average variance explained is the squared of the loadings. Given that the loadings of LSE, COB and CP are all higher than 0.7, it implies that their AVE are above 0.5 minimum criterion. OCB has 11 items with four items with loadings of between 0.65 and 0.7 , however since seven items have loadings well above 0.7 , it implies that the AVE of OCB is approximately 0.5 (Wong, 2013).

CFI and RMSEA measure the model fit. CFI is above 0.9 while RMSEA is 0.049 . These values are above their minimum values (CFI $\geq 0.9$; RMSEA = approximately equal to zero), which implies that the model is fit and can be relied upon. The overall model fit indicates that the minimum level is achieved. The four factors structure model chi-square yield a relatively satisfactory value of 1547.608 with degree of freedom of 773 . The value of the RMSEA is 0.49 while the value of the CFI is .945 . The relative chi-square (CMIN/df) was estimated to be 2.002 which is below the threshold point of 3.0 and 5.0 suggested by Kline (2005); Hair et al. (2010) and Awang (2014) respectively. In addition, the direction of the magnitude of the loadings was statistically significant with p-value of .000 which is less than .05 . This, therefore, implies that the model is free from offending the estimates and meets the requirement for internal consistency. We therefore conclude that the model is fit.

After this, we went further to test the model by examining the moderating effect of experience on the model when the model was unconstrained and when it was constrained. The researcher started by checking the result of the model when experience was moderated. After running the analysis, the following result was derived:

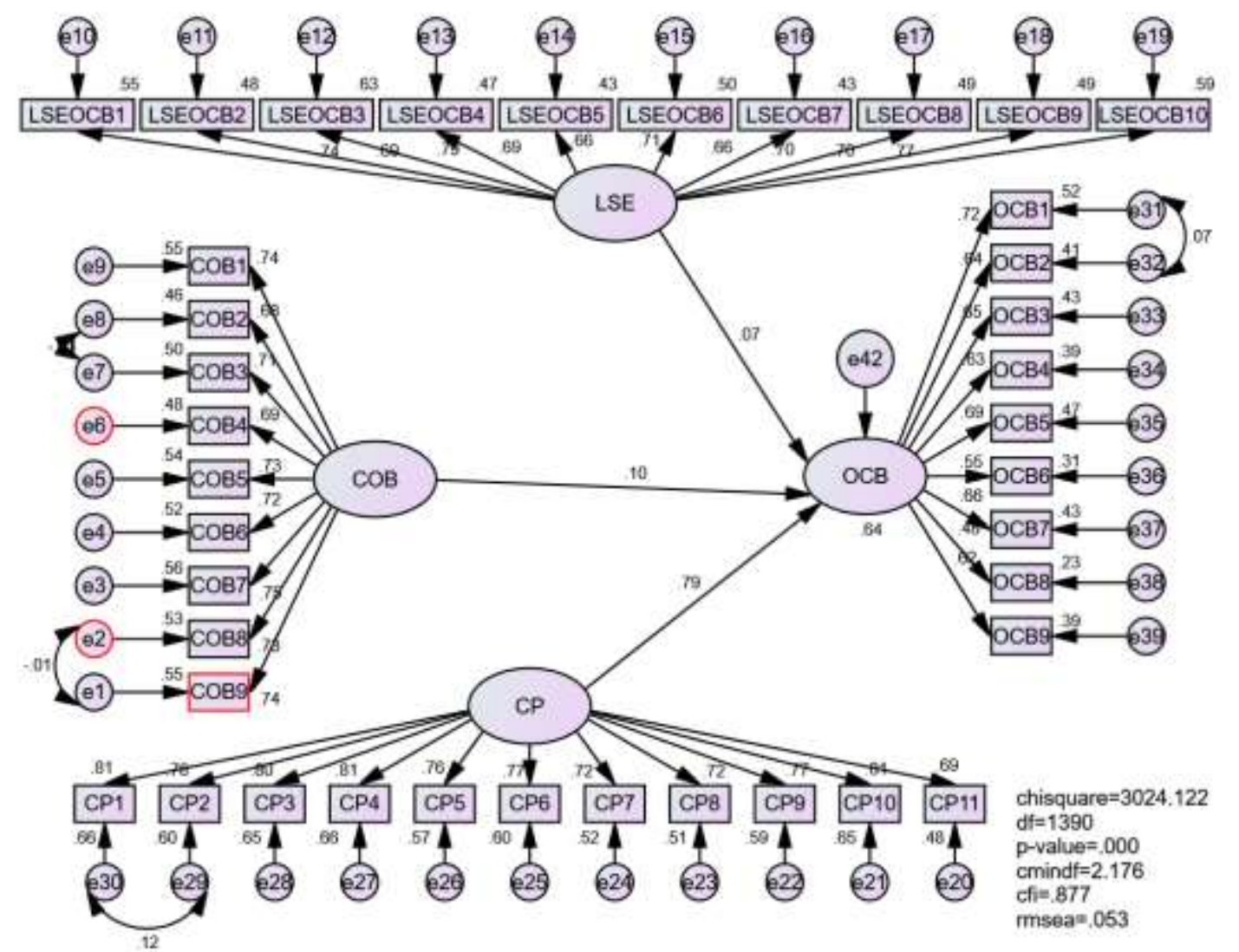

Figure 3. Unconstrained model of more than 10 years when experience moderates. 
Figure 3 above shows the result of the unconstrained model when experience moderates. The p-value of the chi-square is less than 5\% level of significance, which implies that the model fits well. The RMSEA value is .053 with a CFI of .877 and CMIN/Df of 2.176. Next, we need to consider the result of the model when the model is constrained. The three variables contribute 0.64 to the organizational citizenship behavior. It implies that without the model being constrained, the three variables explained $64 \%$ of the organizational citizenship behavior.

Furthermore, the researchers went further by testing for the moderating effect of experience when the model is constraint. After constraining the model for staff with more than 10 years' experience, the researcher arrived at the result below:

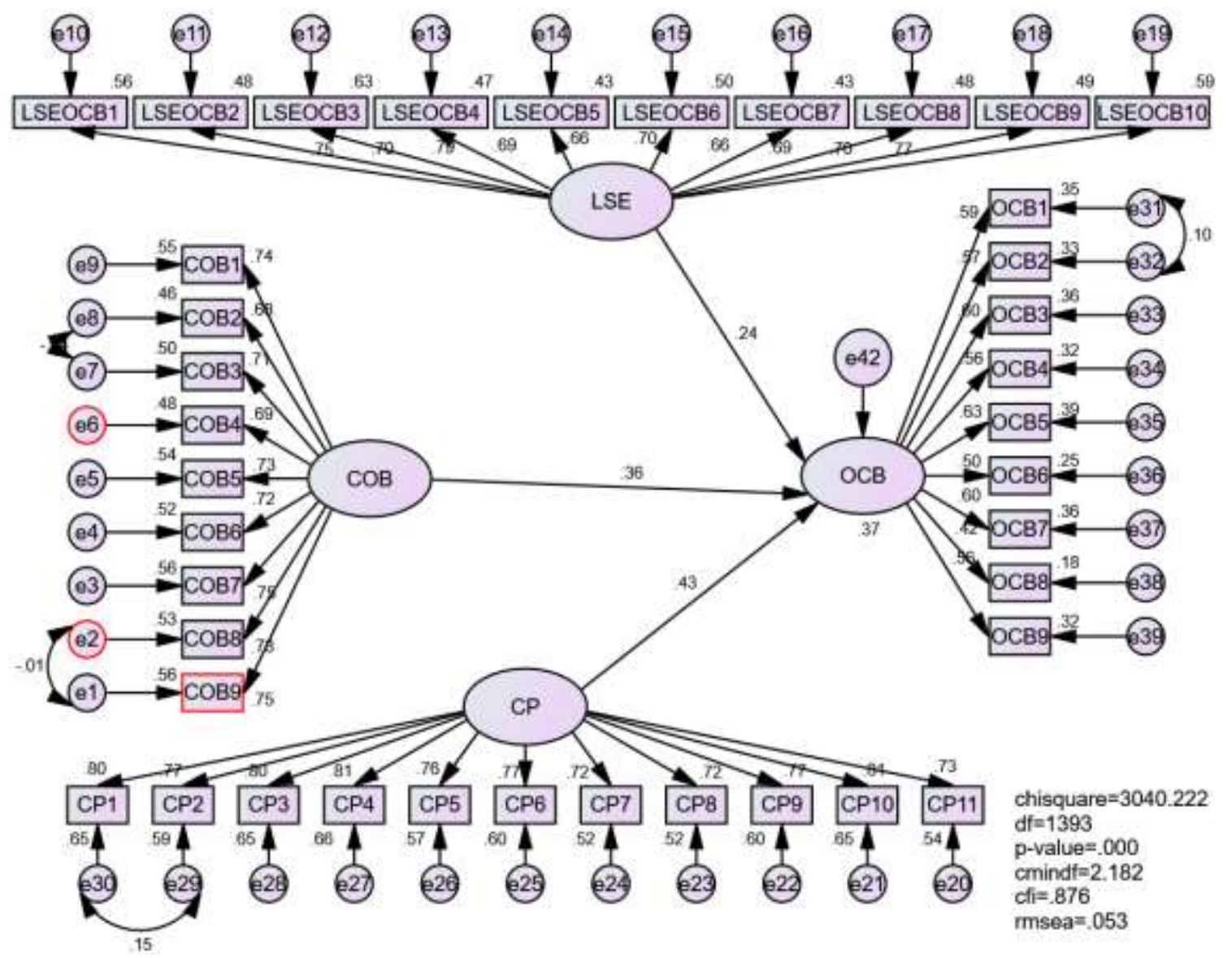

Figure 4. Constrained model of more than 10 years when experience moderates.

Figure 4, above shows the result of the unconstrained model when experience mediates. It was found that the chi-square value changed to 3024.222 with degree of freedom of 1393. The RMSEA value is .053 with a CFI of .876 and CMIN/Df of 2.182. The p-value is also significant at .000 . Here, the three variables contribute 0.37 to the organizational citizenship behavior. This shows that $37 \%$ of the change in organizational citizenship behavior is derived through these three variables. For staff with more than 10 years' work experience, the researcher found that the contribution of these three variables changed when constrained. Therefore, we need to check the table below for the result.

When more than 10 years of experience is constrained, the coefficient of change policy reduces from 0.79 to 0.43 while change oriented behavior increases from 0.1 to 0.36 and leadership self-efficacy increases from 0.07 to 0.24 . The moderating effect of more than 10 years of work experience has indication for increasing level of leadership self-efficacy and change oriented behavior and decreasing level of change policy. 
Table 3. Moderation Test for Staff with More Than 10 Years Work Experience

\begin{tabular}{llllll}
\hline Item & $\begin{array}{l}\text { Constraint } \\
\text { Model }\end{array}$ & $\begin{array}{l}\text { Unconstraint } \\
\text { Model }\end{array}$ & $\begin{array}{l}\text { Chi-Square } \\
\text { Diff. }\end{array}$ & T-Value & Remark \\
\hline Chi-Square & 3040.222 & 3024.122 & 16.100 & 7.815 & Significant \\
Df & 1393 & 1390 & & 3 & \\
CMIN/Df & 2.182 & 2.176 & & & \\
RMSEA & .053 & .053 & & & \\
CFI & .876 & .877 & & & \\
P-Value & .000 & .000 & & & \\
\hline
\end{tabular}

In the table 3 above, the difference in chi-square result is 16.100 (3040.22 - 3024.122) while the difference in degree of freedom is 3 . The table value using the chi-square table under .050 is 7.815 . This shows that the calculated value is greater than the tabulated value $(16.100>7.815)$. Since the table value is less than the calculated value, it, therefore, implies that high experience moderates the relationship between leadership self-efficacy, change-oriented behavior, change policy and organizational citizenship behavior of staff in higher education institutions.

In addition, the researcher considered the moderating effect of less than 10 years' work experience. This produces the following result.

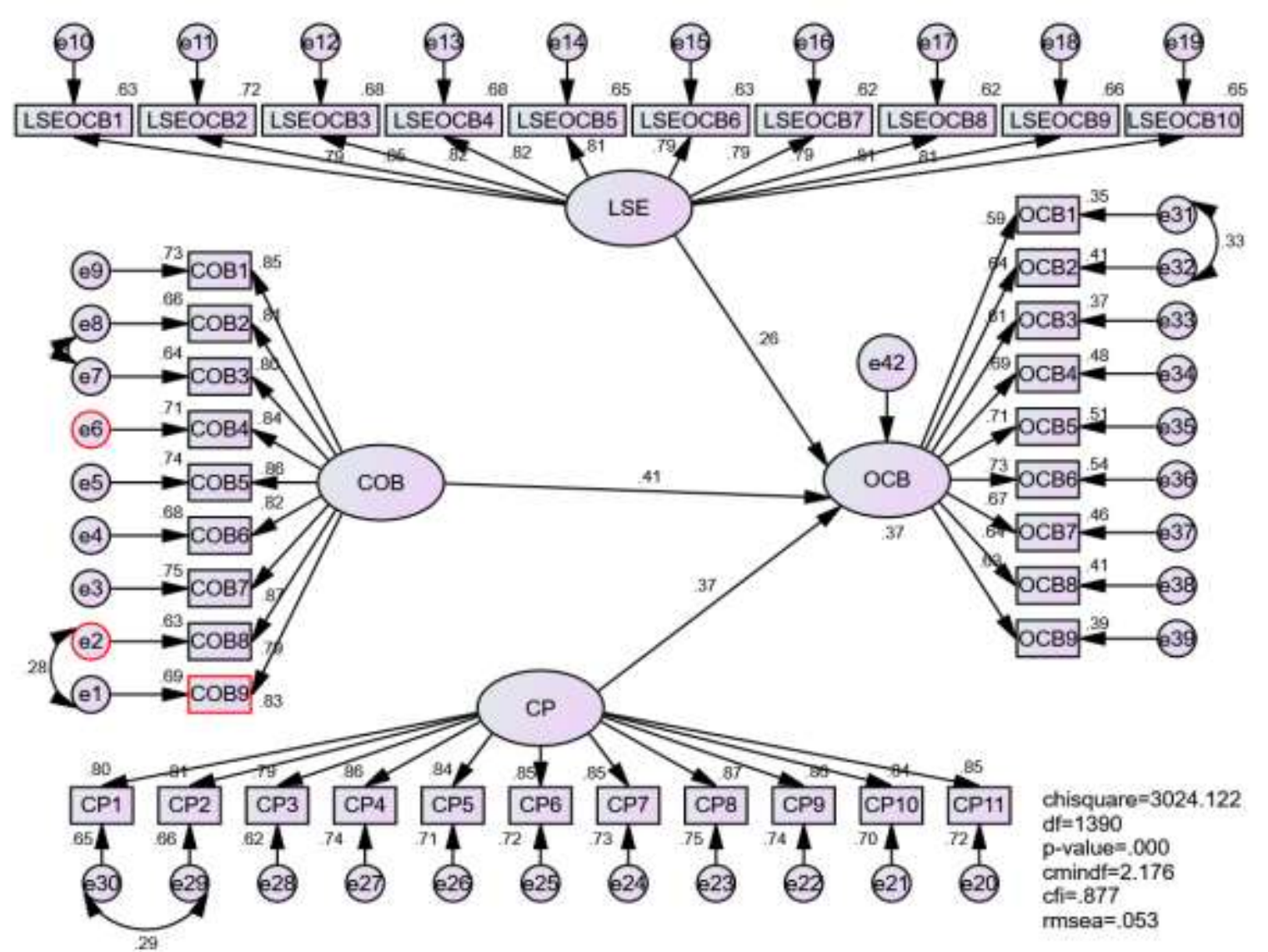

Figure 5. Unconstrained model of less than 10 years when experience mediates.

Figure 5 above shows the result of the unconstrained model of less than 10 years when experience mediates. It was found that the chi-square value changed to 3024.122 with degree of freedom of 1390 . The RMSEA value is .053 with a CFI of .877 and CMIN/Df of 2.176. The p-value is also significant at .000 . Next, we need to consider the result of the model when the model is constrained. The three variables contributed 0.37 to the organizational citizenship behavior. It implies that without the model being constrained, the three variables explained $37 \%$ of the organizational citizenship behavior. The next step is to constrain the model for less than 10 years' work experience and make a comparison. 


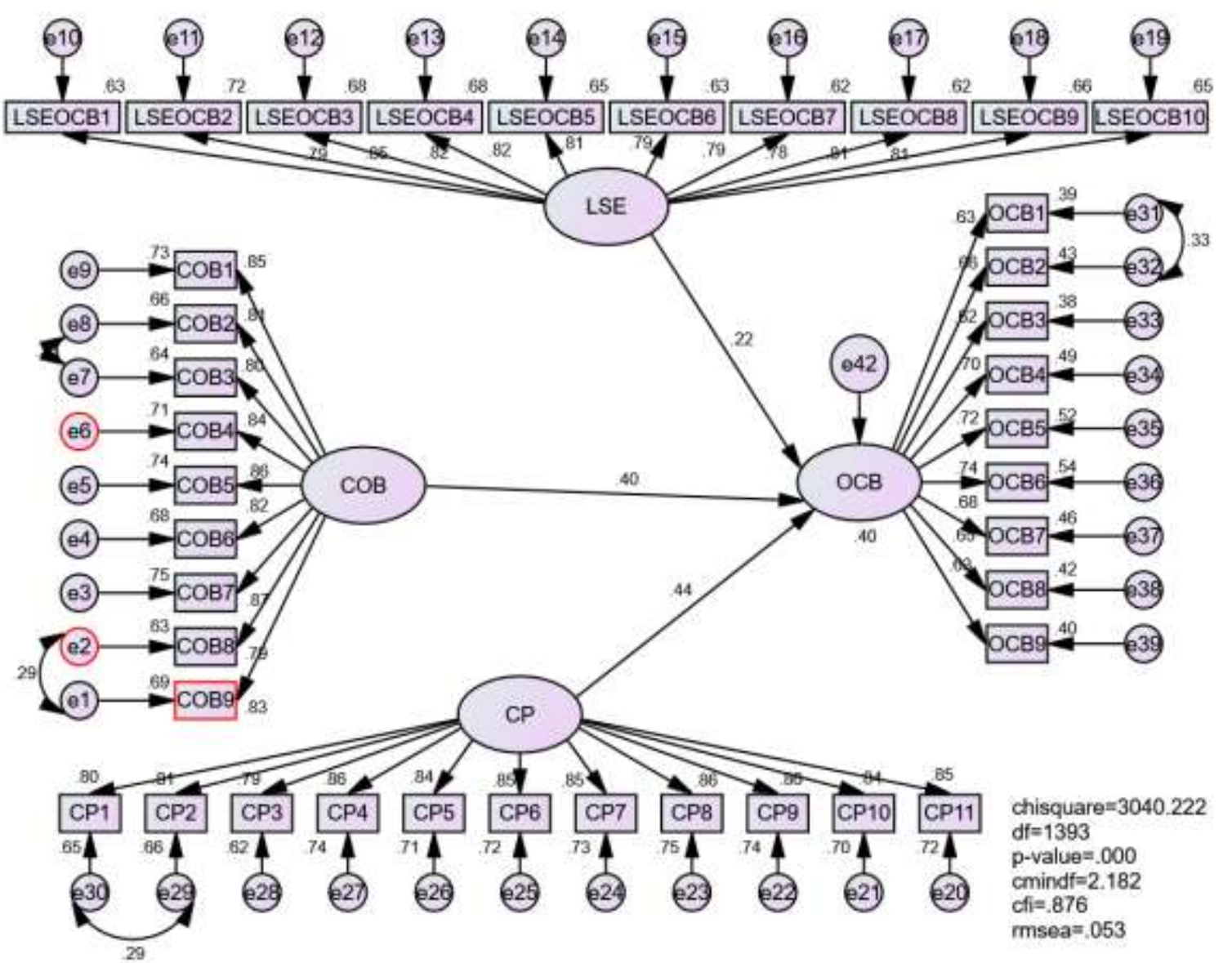

Figure 6. Constrained model of less than 10 years when experience moderates.

Figure 6 above shows the result of the unconstrained model when experience moderates. It was found that the chi-square value changed to 3024.222 with degree of freedom of 1393 . The RMSEA value is .053 with a CFI of .876 and CMIN/Df of 2.182. The p-value is also significant at .000. Here, the three variables contributed 0.40 to the organizational citizenship behavior. This shows that $40 \%$ of the change in organizational citizenship behavior was derived through these three variables. For staff with less than 10 years' work experience, the researcher observed that the contribution of these three variables changed when constrained. Therefore, the researcher checked the table below for the result.

When less than 10 years of experience is constrained, the coefficient of change policy reduces from 0.79 to 0.44 , change oriented behavior increases from 0.1 to 0.40 and leadership self-efficacy increases from 0.07 to 0.22 . The moderating effect of less than 10 years of work experience has indication for increasing level of leadership self-efficacy and change oriented behavior and decreasing level of change policy.

Table 4. Moderation Test for Staff with Less Than 10 Years Work Experience

\begin{tabular}{llllll}
\hline Item & $\begin{array}{l}\text { Constraint } \\
\text { Model }\end{array}$ & $\begin{array}{l}\text { Unconstraint } \\
\text { Model }\end{array}$ & $\begin{array}{l}\text { Chi-Square } \\
\text { Diff. }\end{array}$ & T-Value & Remark \\
\hline Chi-Square & 3040.222 & 3024.122 & 16.100 & 7.815 & Significant \\
Df & 1393 & 1390 & & 3 & \\
CMIN/Df & 2.182 & 2.176 & & & \\
RMSEA & .053 & .053 & & & \\
CFI & .876 & .877 & & & \\
P-Value & .000 & .000 & & & \\
\hline
\end{tabular}

Table 4 above shows that the difference in chi-square result is 16.100 (3040.22-3024.122), while the difference in degree of freedom is 3 . The table value is 7.815 . This shows that the calculated value is greater than the tabulated 
value $(16.100>7.815)$. Since the table value is less than the calculated value, it, therefore, implies that high experience moderates the relationship between leadership self-efficacy, change-oriented behavior, change policy and organizational citizenship behavior of staff in higher education institutions.

As a conclusion of this, it was found that work experience of staff (both more than 10 years and less than 10 years) is statistically significant with p-value of .000. Since the calculated value for these two levels is more than their table value. Therefore, we will accept the alternative hypothesis and fail to accept the null hypothesis. This implies that experience moderates the relationship between leadership self-efficacy, change oriented behavior, change policy and staff organizational citizenship behavior in higher education institutions.

\section{Discussion}

In this research study, work experience moderates the relationship between leadership self-efficacy, change oriented behavior, change policy and staff organizational citizenship behavior in higher education institutions. Experience counts in staff display of organizational citizenship behavior. Even if academic leaders should display high self-efficacy, with good change oriented behavior and change policy, experience of the individual member of staff is required in stimulating their display of organizational citizenship behavior.

Base on the result of the findings, it was evident that leadership self-efficacy, change oriented behavior and change policy account for $37 \%$ change in staff organizational citizenship behavior for staff with less than 10 years' work experience when the model was constraint while these variables account for $64 \%$ change in staff organizational citizenship behavior when it was not constraint. In the contrast, leadership self-efficacy, change oriented behavior and change policy account for $40 \%$ change in organizational citizenship behavior of staff with more than 10 years' work experience while these independent variables account for only $37 \%$ change in staff organizational citizenship behavior for staff with more than 10 years' work experience when unconstraint. This result reveals that staff with less than 10 years' work experience display higher percentage of organizational citizenship behavior when compare with their counterpart with more than 10 years' work experience. This variation in the display of organizational citizenship behavior by these two categories of staff occur as a result of that fact that junior staff with few years of work experience are showing more commitment and ready to go extra mile in order to get to the top because these staff need promotion and are always ready to abide by instruction given by their institutions and leaders while those at the top (with longer year of service) are not exercising more effort because some of them have reached their climax. It can therefore be deduced from the result of this findings that staff with less than 10 years exhibit more prosocial value motives than their counterpart who have more than 10 years' work experience. This implies that more of the respondent with less than 10 years' experience are willing to be helpful and more ready to build positive relationship with others than those who have spent more than 10 years in service. This findings corresponds with the findings of Rioux and Penner (2001) who argued that when staff or employee exhibits prosocial values motives it will enhance their display of organizational citizenship behavior.

Furthermore, the result of the moderating effect of both less than 10 years and more than 10 years shows that the $\mathrm{p}$-value of these two categories of staff experience are both statistically significant with $\mathrm{p}=.000$ each. This therefore implies that experience moderates the relationship among leadership self-efficacy, change oriented behavior, change policy and organizational citizenship behavior of staff. This is in agreement with some past studies. In a study conducted by Adebayo (2018) it was found that experience is a vital factor in staff display of organizational citizenship behavior in higher education institutions. Similarly, Kotur and Anbazhagan (2014) found that experience influences workers leadership style. This view was also supported by Bandura (2007) who found that experience is a vital tool which enhances self-efficacy of individual. Furthermore, experience influences the display of organizational citizenship behavior as Nilankant and Ramnarayan (2006) argued that the experience of people is usually transferred to the workplace and enhances their performance in an organization. In addition, the finding of $\mathrm{Ng}$ and Feldman (2013) supports this when they found that experience has significant effect on citizenship behavior of workers. This was also corroborated by the findings of Avolio et.al (1990) who stressed that experience acquired by workers enhances their performance in the work place. From all indication, it is evident that experience is an important factor with can make or mar individual and organizations.

The findings of this research study has practical and theoretical implication on higher education management, leadership and governance. It shows that experience counts a lot in organizational citizenship behavior and attaining organizational goals. Theoretically, this paper contribute to the self-efficacy theory by using experience to increase the predicative powers of change policy, leadership self-efficacy and change oriented behavior in organizational citizenship behavior. Practically, experience of both leaders and followers counts in their display of effective leadership and organizational citizenship behavior in higher education institutions. Leaders need experience to 
enhance their self-efficacy, lead the path of change, formulating and implementing change ideas in their organizations, mobilize followers towards imbibing the change ideas, managing organizational policies and assisting their subordinates in displaying organizational citizenship behavior. Therefore, leaders must learn from their past experience and apply their previous experience in enhancing effective organization and staff development. Also, experience of followers will drive them towards improving their organizational citizenship behavior.

In addition, policy makers should ensure that experience is put into consideration before appointing right personnel into leadership positions in higher education institutions. Therefore, for experience of academic leaders to count and play significant role in enhancing staff organizational citizenship behavior in higher education institutions in developing countries, it must be applied sincerely and objectively. With experience, leaders can achieve a lot and influence subordinates to achieve organizational goals. Furthermore, experience of followers count in their daily interaction and discharge of their duties. Therefore, experience should be considered as a vital point in selecting staff into higher education institutions and positions. Staff with high experience are likely to perform better than those with less experience.

\section{Conclusion}

Experience is a moving force in learning. It contributes a lot in human relation and organizational development. As shown above, experience moderates the relationship between leadership self-efficacy, change oriented behavior, change policy and staff organizational citizenship behavior in higher education institutions in Lagos State, Nigeria. Staff display of organizational citizenship behavior in higher education institutions can be influenced by experience. Therefore, its role in enhancing organizational performance cannot be overemphasized. Also, it impact on the performance of leaders and followers in higher education institutions. If experience is seen as an integral aspect of higher education process and given its due place in our higher education institutions, soon, higher education institutions in developing countries will perform better and achieve goals for which they were established. However, this study is limited to members of staff in public higher education institutions in Lagos State Nigeria as a result of limited resources.

\section{References}

Abu Nasra, M., \& Helibrunn, S. (2015). Transformational leadership and organizational citizenship behaviour in Arab educational system in Israel: The impact of trust and job satisfaction. Educational Management, Administration and Leadership, 44(3), 1 - 17. https://doi.org/10.1177/1741143214549975

Abu Tineh, A.M., Khasawneh, S.A., \& Omary, A.A. (2009). Kouzes and Posner's transformational leadership model in practice: The case of Jordanian schools. Journal of leadership education, 7(3), 265-283. https://doi.org/10.12806/V7/I3/RF10

Adebayo, S.A., \& Ghavifekr, S. (2019). Leadership self-efficacy and staff organizational citizenship behavior in higher education institutions: Experience from Nigeria. International Journal of Leadership in Education. https://doi.org/10.1080/13603124.2018.1543540

Adebayo, S.A. (2018). Impact of leadership self-efficacy and change oriented behaviour on staff organizational citizenship behaviour in Nigerian higher education institutions. University of Malaya: Unpublished PhD Thesis.

Adebayo, S.A., Ghavifekr, S., \& Megat Daud, M.A. (2018). Leadership and staff organizational citizenship behaviour in higher education institutions: A quantitative analysis. Malaysian Online Journal of Educational Management, 6(1), 36 -52. https://doi.org/10.22452/mojem.vol6no1.3

Agarwal, P. (2016). Redefining the organizational citizenship behaviour. International Journal of Organizational Analysis, 24 (5), 956 - 984. https://doi.org/10.1108/IJOA-12-2014-0826

Aina, J.K., Nathaniel, N.G., \& Ibitomi, O.S. (2017). The lack of good governance in Nigeria and its impact on functional science education. International Journal of Development and Sustainability, 6(9), 1036 - 1047.

Airola, D.T., Bengston, E., Davis, D.A. \& Peer, D.K. (2014). Principals' sense of efficacy: The influence of the Arkansas Leadership Academy. Journal of Educational Administration, 52(6), $754 \quad-\quad 774$ https://doi.org/10.1108/JEA-08-2013-0089

Anderson, D. W., Krajewski, H.T., Goffin, R.D., \& Jackson, D.N. (2008). A leadership self-efficacy taxonomy and its relation to effective leadership. The Leadership Quarterly, 19(5), $595 \quad-\quad 608$. https://doi.org/10.1016/j.leaqua.2008.07.003 
Anya, O.A (2013). The idea and uses of university in the 21st century. 2013 Convocation Lecture. Port Harcourt: University of Port Harcourt.

Avolio, B. J., Gardner, W. L., Walumbwa, F. O., Luthans, F., \& May, D. R. (2004). Unlocking the mask: A look at the process by which authentic leaders' impact follower attitudes and behaviors. The Leadership Quarterly, 15(6), 801-823. https://doi.org/10.1016/j.leaqua.2004.09.003

Avolio, B. J., Waldman, D. A., \& McDaniel, M. A. (1990). Age and work performance in non-managerial jobs: The effects of experience and occupational type. Academy of Management Journal, 33(2), 407-422. https://doi.org/10.5465/256331

Awang, Z. (2014). A handbook of structural equation modelling for academicians and practitioners. Kuala Lumpur: MPWS Rich Resources.

Babara, S. \& Swailes, S. (2010). Organizational change. (4th ed.). England: Financial Times Prentice Hall.

Bandura, A \& Locke, E. A. (2003). Negative self-efficacy and goal effects revisited. Journal of Applied Psychology, 88(1), 87-99. https://doi.org/10.1037/0021-9010.88.1.87

Bandura, A. (1997). Self-efficacy: The exercise of control. New York: W. H. Freeman.

Bandura, A. (2004). Cultivate self-efficacy for personal and organizational effectiveness. In Locke, E.A(Ed), Handbook of principles of organizational behaviour. Malden, M.A: Blackwell.

Bandura, A. (2007). Much ado over a faculty conception of perceived self-efficacy grounded in faculty experimentation. Journal of Social and Clinical Psychology, 26(6), 641-658. https://doi.org/10.1521/jscp.2007.26.6.641

Barclay, L.A., Mellor, S., Bulger, C.A., \& Kath, L.M. (2007). Perceived steward success and leadership efficacy: The role of gender similarity. Journal of Collective Negotiations, 31,141 - 153. https://doi.org/10.2190/CN.31.2.c

Bass, B.M. (2010). The Bass handbook of leadership: Theory, research and managerial applications. New York, NY: Simon \& Schuster.

Bettin, P.J., \& Kennedy Jr., J.K. (1990). Leadership experience and leader performance: Some empirical support at last. The Leadership Quarterly, 1(4), 219 - 228. https://doi.org/10.1016/1048-9843(90)90002-Y

Bolu, C.A. \& Egbo, K. (2014). The role of higher education institutions in the development of ICT professionals for innovations in Nigeria. International Journal of Engineering Innovation and Research, 3(1), 1-7.

Braun, S.,Nazlic, T., Weisweiler, S., Pawlowska, B., Peus, C., \& Frey, D. (2009). Effective leadership development in higher education: Individual and group level approaches. Journal of Leadership Education, 8(1), 195 - 206. https://doi.org/10.12806/V8/I1/IB6

Brown, D.J., \& Keeping, L.M. (2005). Elaborating the construct of transformational leadership: The role of affect. Leadership Quarterly, 16, 245-272. https://doi.org/10.1016/j.leaqua.2005.01.003

Bryman, A., \& Lilley, S. (2009). Leadership researchers on leadership in higher education. Leadership, 5(3), 331 346. https://doi.org/10.1177/1742715009337764

Bryne, B.M. (2010). Structural equation modelling with AMOS: Basic concepts, applications and programming. (2nd ed.). New York: Routledge.

Bukhari, Z.U. (2008). Key antecedents of organizational citizenship behaviour in banking sector of Pakistan. International Journal of Business and Management, 3(12), $106 \quad-.115 . \quad$ D https://doi.org/10.5539/ijbm.v3n12p106

Bush, T. (2008). Theories of educational leadership and management. (4th ed.) London: Sage Publication.

Bush, T., \& Middlewood, D. (2005). Leading and managing people in education. London: Sage Publication.

Cattell, R.B. (1966). The screen test for number of factors. Multivariate Behavioral Research, 1, $245-276$. https://doi.org/10.1207/s15327906mbr0102_10

Cawsey, T.F., Desca, G., \& Ingols, C. (2012). Organizational change: An action-oriented toolkit. (2nd ed.) Los Angeles: Sage Publication. 
Chan, S.H. (2010). The influence of leadership expertise and experience on organizational performance: A study of Amanah Ikhtiar Malaysia. Journal of Asia Pacific Business Review, 16(1-2), 59 - 77. https://doi.org/10.1080/13602380802503566

Chemers, M.M., Watson, C.B., \& May, S.T. (2000). Dispositional effect and leader effectiveness: A comparison of self-esteem, optimism and efficacy. Personality and Social Psychology Bulletin, 26, 267 - 277. https://doi.org/10.1177/0146167200265001

Chuang, S.F. (2013). Essential skills for leadership effectiveness in diverse workplace development. Online Journal for Workforce Education and Development, 6(1), 1-23.

Civelek, M.E. (2018). Essentials of structural equation modeling. Lincoln Nebraska: Zea Books. https://doi.org/10.13014/K2SJ1HR5

Collins, J.P. (2014). Leadership and change in twenty-first century higher education. Bio Science, 64(7), 561 - 562. https://doi.org/10.1093/biosci/biu080

Creswell, J.W. (2012). Educational research: Planning, conduction and evaluating quantitative and qualitative research (4th ed.) Boston: Pearson.

Dawson, P. \& Andriopoulos, C. (2014). Managing change, creativity and innovation. Los Angeles: Sage Publication.

Ehtiyar, V.R., Aktas, A.A., \& Omuris, E. (2010). The role of organizational citizenship behaviour on student's academic success. Tourism and Hospitality Management, 16(1), 47-61. https://hrcak.srce.hr/64579

Ejimabo, N.O. (2013). Understanding the impact of leadership in Nigeria: Its reality, challenges and perspectives. SAGE Open, April - June, 1 - 14. https://doi.org/10.1177/2158244013490704

Farh, J.L., Zhong, C.B., \& Organ, D.W. (2004). Organizational Citizenship Behavior in the People's Republic of China. Organization Science, 15(2), 241-253. https://doi.org/10.1287/orsc.1030.0051

Farooqii, M.R. (2012). Measuring organizational citizenship behaviour as a consequence of organizational climate. Asian Journal of Business and Management, 4(3), 294 - 302.

Fernandez, S. (2008). Examining the effects of leadership behavior on employee perceptions of performance and job satisfaction. Journal of Public Performance and Management Review, 32(2), 175 - 205. https://doi.org/10.2753/PMR1530-9576320201

Foote, D.A., \& Tang, T.L. (2008). Job satisfaction and organizational citizenship behaviour: Does team commitment make a difference in self-directed teams. Management Decision, 46(6), 933-947. https://doi.org/10.1108/00251740810882680

Fraenkel, J.R., Wallen, N.E., \& Hyun, H.H. (2015). How to design and evaluate research in education. (9th Ed.). New York: McGraw Hill Education.

George, J.M., \& Jones, G.R. (2012). Understanding and managing organizational behaviour. (6th ed.). Boston: Pearson Education Limited.

Glaser, J.E. (2006). Creating we and change i-thinking to we-thinking: Building a healthy, thriving organization. Pertaling Jaya, Malaysia: PB Publications.

Hair, J.F., Hult, G.T.M., Ringle, C.M., Sarstedt, M., \& Thiele, K.O. (2017). Mirror, mirror on the wall: A comparative evaluation of composite-based structural equation modeling methods. Journal of the Academy of Marketing Science, 45(5), 616 - 632. https://doi.org/10.1007/s11747-017-0517-x

Harris, A. (2008). Leading sustainable schools. London: Specialist Schools and Academic Trust. Implementation.

Ijaz, M.,Shahinshah, B.K., Khan, R., Shaheen, A.T. (2012). Role of academic leadership in change management for quality in higher education in Pakistan. Journal of Education and Practice, 3(16),194 - 198.

Jutila, H. (2007). A critical appraisal of current change management practices in the business environment of the early 21st century: Organizational change and how it was perceived in Hameelinna Regional Environmental Authority. Finland: Hameelinna Regional Environmental Authority.

Kaiser,H. (1970). A second generation little jiffy. Psychometrika, 35, $401 \quad-\quad 415$ https://doi.org/10.1007/BF02291817 
Kotur, B.R., \& Anbazhagan, S. (2014). The influence of education and work experience on leadership styles. IOSR Journal of Business and Management, 16(2), 103 - 110. https://doi.org/10.9790/487X-1621103110

Kouzes, J.M \& Posner, B.Z, \& Dekrey, S. (2013). Making extra-ordinary things happen in Asia: Applying the five practices of exemplary leadership. San Fracisco: Jossey-Bass.

Kouzes, J.M \& Posner, B.Z. (2007). The leadership challenge (4th ed.). San Francisco, CA: Jossey-Bass.

Kouzes, J.M \& Posner, B.Z. (2003). Academic administrator's guide to exemplary leadership. San Francisco, CA: Jossey-Bass.

Kouzes, J.M \& Posner, B.Z. (2002). Leadership challenges (3rd ed.). San Francisco,CA: Jossey-Bass.

Kraska-Miller, M. (2014). Non-parametric statistics for social behavioural sciences. New York: CRC Press. https://doi.org/10.1201/b16188

Krejcie, R.V., \& Morgan, D.W. (1970). Determining sample size for research. Educational and Psychological Measurement, 30, 607 - 610. https://doi.org/10.1177/001316447003000308

Leaming, D.R. (1999). Academic leadership: A practical guide to chairing the department. Bolton: Anker Publishing Company, Inc.

Lunenburg, F. (2011). Self-efficacy in the workplace: Implications for motivation and performance. International Journal of Management, Business and Administration, 14(1), 1-6.

Mayers,A. (2013). Introduction to statistics and SPSS in psychology. Edinburg Gate: Pearson Education Limited.

Moore, M.R., \& Diamond, M.A. (2000). Academic leadership: Turning vision into reality. Australia: The Ernst and Young Foundation.

Nakpodia, E. D. (2012). Leadership development skills: a Nigeria educational institutions review. Global Business and Economics Research Journal, 1(2), 93-110.

Neuman, W.L. (2014). Understanding research. Pearson New International Edition (1st ed). England: Pearson Education Limited.

Ng, T. M.H., \& Feldman, D.C. (2013). Does longer job tenure help or hinder job performance?. Journal of Vocational Behavior, 83(3), 305 - 314. https://doi.org/10.1016/j.jvb.2013.06.012

Nilakant, V., \& Ramnarayan, S. (2006). Change management: Altering mindsets in a global context. New Delhi: Response Books.

Ogunruku, A.O. (2012). University administration in the $21^{\text {st }}$ century: A new direction. Ile-Ife: Obafemi Awolowo University Press.

Okoroma, N.S. (2006). Educational policies and problems of implementation in Nigeria. Australian Journal of Adult Learning, 46(2), $243-263$.

Organ, D. W., Podsakoff, P. M., \& MacKenzie, S. B. (2006). Organizational citizenship behaviour. California: Sage Publications.

Organ, D.W. (1997). Organizational Citizenship Behavior: Its construct clean-up time. Human Performance, 10(2), 85-97. https://doi.org/10.1207/s15327043hup1002_2

Osipova, A., \& Ayupova, G. (2013). Change management in project work: Survey result. United Kingdom: Deloitte.

Owens, R.G \& Valesky, T.C. (2011). Organizational behavior in education: Leadership and school reform. (10th edition). Boston: Pearson.

Paglis, L.L., \& Green, S.G. (2002). Leadership self-efficacy and managers' motivation for leading change. Journal of Organizational Behavior, 23, 215 - 235. https://doi.org/10.1002/job.137

Paglis, L.L. (2010). Leadership self-efficacy: Research findings and practical applications. Journal of Management Development, 12(9), 771 - 782. https://doi.org/10.1108/02621711011072487

Partridge, L. (2007). Managing change: Learning made simple. Amsterdam: Elsevier. https://doi.org/10.4324/9780080554143

Podsakoff, N.P., Whiting, S.N., Podsakoff, P.M., Blume, B, D. (2009). Individual and organizational level consequences of organizational citizenship behavior: A meta-analysis. Journal of Applied Psychology, 94(1), 122-141. https://doi.org/10.1037/a0013079 
Podsakoff, P. M., MacKenzie, S. B., Paine, J. B., \& Bachrach, D. G. (2000). Organizational citizenship behaviors: a critical review of the theoretical and empirical literature and suggestions for further research. Journal of Management, 26(3), 513-563. https://doi.org/10.1177/014920630002600307

Rubin, A., \& Rabbie, E.R. (2014). Research methods for social work (8th ed.). Australia: Brooks/Cole Cengage Learning.

Sahin, I., Akyuren, C.E., \& Yavuz, S. (2014). Assessment of effect of leadership behaviour perceptions and organizational commitment of hospital employees on job satisfaction with structural equation modeling. Journal of Health Management, 16(2), 161 - 182. https://doi.org/10.1177/0972063414526111

Somech, A. (2006). The effects of leadership style and team process on performance and innovation in functionally heterogeneous teams. Journal of management, 32(1), 132-157. https://doi.org/10.1177/0149206305277799

Spendlove, M. (2007). Competencies for effective leadership in higher education. International Journal of Educational Management, 21(5), 407 - 417. https://doi.org/10.1108/09513540710760183

Tabachnick, B.G., \& Fidell, L.S. (2013). Using multivariate statistics (6th ed.). Boston: Pearson Education Inc.

Tang, K., MacDermid, J.C., Amick, B.C \& Beaton, D.E. (2011). The 11-item workplace organizational policies and practices questionnaire (OPP-11): Examination of its construct validity, factor structure and predictive validity in injured workers with upper-limb disorder. American Journal of Industrial Medicine, 54(11), 834-846. https://doi.org/10.1002/ajim.20994

Van der Bijl, J. J., \& Shortridge-Baggett, L. M. (2002). The theory and measurement of the self-efficacy construct. In E. A. Lentz \& L. M. Shortridge-Baggett (Eds.), Self-efficacy in nursing: Research and measurement perspectives. New York: Springer.

Wong, K.K.K. (2013). Partial least square structural equation modeling (PLS-SEM) techniques using SmartPLS. Marketing Bulletin, 24(1), 1 - 32.

Yukl, G. (2010). Leadership in organizations, (7th ed.). Upper Saddle River, New Jersey: Prentice Hall.

Zolfaghari,A. (2015). The necessity and importance of education for social and cultural development of societies in developing countries. Cumhuriyet Science Journal, 36, 3380-3386. 